\title{
Jaringan Nomologis Rasionalitas Epistemik dengan Inteligensi dan Perfeksionisme
}

\author{
Seisar Winengku Handani ${ }^{1} \mathcal{E}$ Rahmat Hidayat ${ }^{2}$ \\ Fakultas Psikologi, Universitas Gadjah Mada
}

\begin{abstract}
Rationality is a human's ability to think clearly in order to achieve his goals. Rationality has two types, epistemic and instrumental. Epistemic rationality is related judgment and instrumental rationality is related to decision making. This research aims to validate the nomological network between epistemic rationality, intelligence, and perfectionism. It also aims to analyze the latent factor of three variables. The subject of this research is 67 college student from several universities in Yogyakarta. Data collection was held using CBT to measure epistemic rationality and perfectionism while paper and pencil were used to measure intelligence. The result shows that in measurement level, epistemic rationality does not shape the nomological network with intelligence and perfectionism. However, this research found that three variables have two latent factors based on convergence and divergence factor analysis.
\end{abstract}

Keywords: epistemic rationality; intelligence; perfectionism; rationality

\begin{abstract}
Abstrak. Rasionalitas merupakan kemampuan manusia berpikir untuk dengan baik dalam rangka mencapai tujuan karena pada hakikatnya, tujuan menjadi yang utama di dalam rasionaltas. Rasionalitas dibagi menjadi dua tipe, yaitu epistemik dan instrumental. Rasionalitas epistemik berkaitan dengan penilaian dan rasionalitas instrumental berkaitan dengan pengambilan keputusan. Tujuan penelitian ini untuk memeriksa jaringan nomologis antara rasionalitas epistemik dengan inteligensi dan perfeksioniemse serta melihat faktor laten ketiga variabel dari konvergensi dan divergensi yang terbentuk. Subjek penelitian berjumlah 67 orang yang merupakan mahasiswa dari beberapa universitas di Yogyakarta. Pengambilan data menggunakan Computer Based-Test untuk rasionalitas epistemik dan perfeksionisme, sedangkan untuk inteligensi menggunakan paper and pencil. Hasil penelitian menunjukan bahwa pada level pengukuran, rasionalitas epistemik tidak membentuk jaringan nomologis dengan inteligensi dan perfeksionisme, namun pada level konsep ketiga variabel membentuk jaringan nomologis. Peneltian ini juga menemukan bahwa ketiga variabel memiliki dua faktor laten yang terbentuk berdasarkan konvergensi dan divergensi dari analisis faktor.
\end{abstract}

Kata kunci: inteligensi; perfeksionisme rasionalitas; rasionalitas epistemic

Sering kali kita semua mendengar katakata rasionalitas sehari-hari. Bahkan tidak jarang pula kita semua dituntut untuk menjadi manusia yang rasional (Hidayat, 2016). Sebenarnya apa yang dimaksud dengan rasional? Menurut Kamus Besar

\footnotetext{
${ }^{1}$ Korespondensi mengenai isi artikel ini dapat dilakukan melalui swinengkuh@gmail.com

${ }^{2}$ Atau melalui r.hidayat@ugm.ac.id 
Bahasa Indonesia, yang dimaksud dengan rasional adalah menurut pikiran dan pertimbangan yang logis; menurut pikiran yang sehat; sesuai dengan akal (KBBI, 2017). Adapun menurut Baron (2008) rasional artinya berpikir yang terbaik untuk mencapai atau mendapatkan apa yang diinginkan maupun yang menjadi tujuan. Serupa dengan pandangan Baron, Stanovich menjelaskan bahwa manusia rasional adalah yang bertindak untuk mencapai tujuan dengan menggunakan kemungkinan yang terbaik (Stanovich \& West, 2014). Adapula Simon (1972) mengatakan bahwa rasionalitas menunjukkan cara berpikir maupun tindakan yang mengarah pada pencapaian tujuan dengan segala keterbatasan yang ada. Sedangkan menurut Lea (1994) yang dimaksud individu rasional adalah individu yang selalu memikirkan konsekuensi sebelum melakukan tindakan. Rasionalitas juga diartikan sebagai perilaku yang bijaksana, terencana, dan juga konsisten (McFadden, 1998). Dari definisi yang telah dijabarkan, maka dapat diketahui rasionalitas merupakan kemampuan manusia dalam berpikir logis, tepat, masuk akal, serta terencana yang mampu menghasilkan tindakan maupun keputusan berdasarkan berbagai pertimbangan guna mencapai tujuan.

Asumsi homo economicus mengatakan bahwa setiap perilaku manusia pada dasarnya rasional (Simon, 1955; Schwartz et al, 2002). Bahkan Shafir dan LeBoeuf, Santos dan Rosanti menyebutkan bahwa berpikir serta bertindak secara rasional merupakan pencapai tertinggi yang hanya mampu dan dimiliki oleh manusia dibandingkan makhluk hidup lain (dalam Hidayat, 2016). Stanovich, West, dan Toplak (2016) menyebutkan bahwa pemikiran maupun tindakan yang rasional didasari oleh penilaian dan pembuatan keputusan, setiap tindakan untuk meraih tujuan menggunakan konsep maximizing utility dan profit maximizing. Rasionalitas juga sangat penting, dikarenakan rasionalitas merupakan kunci manusia agar bisa survive (Hidayat, 2016). Maksudnya, manusia setiap waktu selalu dihujani berbagai informasi dari berbagai sumber. Dengan adanya rasionalitas, maka manusia mampu melakukan pertimbangan-pertimbangan hingga akhirnya mampu menghasilkan sebuah keputusan sesuai dengan tujuannya yang ingin dicapai. Maka rasionalitas menjadi sangat penting karena berkaitan dengan penilaian dan membuat keputusan yang tentunya selalu dilakukan manusia setiap waktu.

Berbicara mengenai rasionalitas, tentu tidak akan lepas dari penilaian dan pengambilan keputusan, karena keduanya merupakan komponen dari rasionalitas (Stanovich, West, dan Toplak, 2016). Rasionalitas akan berujung pada pembuatan keputusan karena pada hakikatnya berpikir rasional bermuara pada pengambilan keputusan yang rasional. Pengambilan keputusan yang rasional dikenal dengan good thinking artinya pembuatan keputusan di dasari oleh pertimbangan, kalibrasi pengetahuan, serta penyelarasan dengan tujuan (Baron, 2008; Stanovich, 2016). Hastie dan Dawes (2010) menyebutkan bahwa sebuah pengambilan keputusan dianggap rasional apabila memenuhi kriteria sebagai berikut: keputusan tersebut berdasarkan pertimbangan menyeluruh, keputusan tersebut merupakan hasil pertimbangan terhadap hasil atau konsekuensi yang muncul dari keputusan tersebut, keputusan yang berupa kemungkinan diambil berdasarkan teori probabilitas, dan hasil keputusan mencerminkan pertimbangan menyeluruh dari unsur ketidakpastian.

Terdapat dua pandangan yang membahas mengenai rasionalitas, yaitu rasionalitas dari segi ekonomi dan juga psikologi. Ahli ekonomi memandang bahwa manusia yang rasional adalah yang memiliki super 
intelligence yang dilengkapi dengan sumber daya yang memadai, seperti waktu, informasi, dan juga kemampuan komputasional yang tidak terbatas (Gigerenzer, 2001), pandangan tersebut yang kemudian disebut sebagai unbounded rationality. Unbounded rationality memandang bahwa manusia memiliki kemampuan yang tidak terbatas dengan selalu bertindak logis dan berusaha untuk utility maximizing dalam mencapai tujuan. Adapun menurut pandangan ilmu ekonomi tradisional, manusia yang rasional disebut juga economic man. Simon (1978) menyebut economic man adalah manusia yang maximizer expected utility, artinya manusia tersebut hanya akan menempati sesuatu yang terbaik dan memaksimalkan sumber yang ada serta memanfaatkan untuk mencapai tujuan. Seseorang yang maximizer expected utility didefinisikan sebagai manusia yang memilih pilihan berdasarkan pilihan tersebut memiliki nilai maupun harapan yang paling tinggi (Stanovich, 2016).

Berkebalikan dari pendapat ilmu ekonomi mengenai rasionalitas, ilmu psikologi memandang manusia memiliki kemampuan yang terbatas, atau lebih dikenal bounded rationality yang kemudian memunculkan konsep satisficing dan maximizing (Simon, 1955). Dalam pandangan ini, manusia akan cenderung memenuhi satisficing dibandingkan memenuhi utility maximizing. Hal tersebut dikarenakan manusia akan melakukan pertimbanganpertimbangan yang matang untuk membuat suatu keputusan. Maka dapat dikatakan bahwa bahwa dari segi ekonomi manusia yang rasional adalah manusia yang maximizing, sedangkan menurut psikologi manusia yang rasional adalah manusia yang satisficing (Schwartz, Monterosso, Lubomisky, White \& Lehman, 2002).

Selain membagi unbounded dan bounded rationality, Herberts Simon membagi rasionalitas menjadi dua, yaitu rasionalitas substantif dan procedural (Simon, 1976). Pengambilan keputusan di dalam rasionalitas prosedural melibatkan pengumpulan informasi yang relevan, menganalisis informasi tersebut, dan berusaha memilih yang terbaik dari alternatif yang dihasilkan dari infromasi (Walter, Kellermanns, \& Lechner, 2012). Sebaliknya rasionalitas substantif yang menekankan hasil, rasionalitas prosedural lebih menekankan cara atau tindakan yang diambil berdasarkan pertimbangan matang (Munier et al., 1999; Simon, 1976).

Berdasarkan beberapa penjelasan mengenai rasionalitas, maka dapat diketahui bahwa di dalam rasionalitas terdapat proses kognitif, penalaran logis, penggunaan penalaran, yang mana hal-hal tersebut sangat berkaitan dengan kemampuan berpikir. Kemampuan berpikir diukur di dalam tes inteligensi. Maka dari itu tidak heran bahwa rasionalitas sering dikaitkan bahkan tidak jarang disamakan dengan inteligensi (Stanovich \& West, 2014).

Inteligensi secara awam sering dipahami sebagai kecerdasan atau kepintaran. Ketika seseorang memiliki inteligensi yang tinggi maka dianggap bahwa dia cerdas atau pintar. Akan tetapi sebenarnya inteligensi tidaklah sesederhana itu. Inteligensi sendiri merupakan kualitas mental yang menghasilkan nilai-nilai serta performa (Sternberg, 1997). Adapun menurut Terman, inteligensi merupakan tingkat kemampuan pengalaman seseorang untuk menyelesaikan masalah yang sedang dihadapi dan juga mengantisipasi masalah yang akan terjadi (dalam Azwar, 1996).

Asumsi yang berkembang mengenai inteligensi dan rasionalitas menyatakan bahwa keduanya merupakan konstrak yang sama, sehingga ketika sedang mengukur inteligensi (IQ) secara otomatis juga akan mengukur rasionalitas (RQ), jadi $\mathrm{IQ}=\mathrm{RQ}$. Tidak heran banyak yang beranggapan bahwa manusia yang inteli- 
gen adalah manusia yang rasional. Akan tetapi pada kenyataannya tidak demikian, ketika mengukur inteligensi (IQ) maka tidak secara otomatis akan mengukur rasionalitas (RQ), jadi IQ $\neq$ RQ. Kenyataannya, tidak ada komponen rasionalitas (penilaian dan pengambilan keputusan) yang diukur dalam inteligensi (Stanovich, 2016), walaupun penilaian dan pengambilan keputusan juga merupakan cognitive skill sama seperti inteligensi (Stanovich, West, \& Toplak, 2016).

Di dalam dunia riset, memang terdapat dua pandangan mengenai hubungan rasionalitas dan inteligensi. Sebagai contoh penelitian dari Stuart Russell yang mengatakan bahwa inteligensi dan rasionalitas masih dianggap satu kesatuan yang sama. Penelitian tersebut mengungkapkan konsep mengenai inteligensi dan rasionalitas yang dikenal dengan artificial intelligence (AI). Artificial intelligence bukanlah inteligensi pada umumnya yang ada pada manusia, melainkan merupakan inteligensi buatan yang diciptakan untuk sebuah sistem. Sistem tersebut diharapkan dapat menyerupai manusia. Konsep artificial intelligence menyebutkan bahwa rasionalitas terdapat di dalam AI. Lebih jelasnya, Russell menyebutkan bahwa artificial intelligence merupakan penggabungan empat konsep yang di dalamnya terdapat rasionalitas. Keempat konsep tersebut antara lain (Russell, 1997): perfect rationality, calculative rationality, metalevel rationality, dan bounded optimality.

Dari konsep milik Russell maka dapat diketahui bahwa inteligensi dan rasionalitas lagi-lagi dianggap bahwa keduanya bukanlah konsep yang independen. Menurut artificial intelligence, rasionalitas merupakan bagian dari inteligensi. Artinya, rasionalitas masih dianggap belum independen dari inteligensi. Konsep ini masih sejalan dengan asumsi yang berkembang yang menyatakan bahwa $\mathrm{RQ}=\mathrm{IQ}$.
Akan tetapi terdapat beberapa eksperimen yang menyatakan bahwa tidak ada kaitan rasionalitas dengan inteligensi. Sebagai contoh, orang yang memiliki inteligensi rendah tidak lantas melakukan myside bias dibandingkan yang memiliki inteligensi tinggi (Stanovich, West, \& Toplak, 2013). Myside bias sendiri merupakan penyimpangan dalam penilaian dalam bentuk kecenderungan mengandalkan perspektifnya yang telah dimiliki dengan mengabaikan alternatif lain yang lebih masuk akal (Stanovich \& West, 2014). Beberapa komponen rasionalitas seperti base rate neglect, framing effects, conjuction effects, dan anchoring biases juga diketahui tidak memiliki kaitan dengan inteligensi (Stanovich \& West, 2008). Oleh karena terdapat dua pandangan mengenai hubungan rasionalitas dan inteligensi, penelitian ini ingin membuktikan hubungan rasionalitas dan inteligensi dengan menggunakan asumsi dari Stanovich bahwa keduanya merupakan konstrak yang independen.

Selain mencari hubungan rasionalitas dengan inteligensi, penelitian ini juga ingin mencari hubungan rasionalitas dengan perfeksionisme. Rasionalitas diketahui memiliki karakter sama dengan beberapa konstrak lain perfeksionisme seperti maximizer (Schwartz et al., 2002), dan conscientiousness (Benet-Martinez \& John, 1998). Akan tetapi di dalam penelitian ini, ingin melihat hubungan antara rasionalias dengan perfeksionisme. Perfeksionisme merupakan kecenderungan individu untuk menetapkan serta berusaha mencapai standar yang tinggi dan sempurna, akan tetapi bukan karena karena ingin menjadi unggul namun takut akan kegagalan (Sirois \& Molnar, 2016). Peter mengatakan bahwa perfeksionisme sering ditemukan pada seseorang yang memiliki inteligensi di atas rata-rata (dalam Aditomo \& Retnowati, 2004). Seperti yang telah dijelaskan sebelumnya bahwa manu- 
sia yang rasional salah satunya yaitu memiliki super intelligence, artinya sangat memungkinkan rasionalitas memiliki hubungan yang kuat dengan perfeksionisme. Selain itu, seseorang yang perfeksionis secara adaptif diketahui akan berusaha sebaik mungkin untuk mencapai apa yang menjadi tujuannya (Aditomo \& Retnowati, 2004). Hal tersebut sejalan dengan definisi rasionalitas yang mengatakan bahwa manusia yang rasional akan berpikir yang terbaik untuk mencapai apa yang menjadi tujuannya.

Perfeksionisme juga sering dikaitan dengan hal-hal negatif, seperti perasaan gagal, menyesal, ragu-ragu atau bimbang, prokastinasi, serta self esteem rendah (Flett, Hewitt, Blankenstein \& Kaledin, 1991). Seseorang yang perfeksionis akan berusaha untuk menjadi unggul atau sempurna dengan berusaha mencari cara yang terbaik serta mempertimbangkan cara yang akan ditempuh agar terhindar dari kegagalan. Apabila ditelaah lebih lanjut, perfeksionisme memiliki kemiripan dengan rasionalitas prosedural. Sebelumnya telah dijelaskan bahwa rasionalitas prosedural sangat menekankan untuk mempertimbangkan cara yang akan ditempuh agar tujuannya dapat tercapai. perfeksionisme juga memiliki kemiripan dengan rasionalitas epistemik, yang mana kedua sama-sama mempertimbangkan alternatif-alternatif yang tersedia untuk kemudian diyakini sebagai pilihan alternatif yang paling baik. Oleh karena kemiripan antara rasionalitas epistemik dan perfeksionisme, dalam penelitian ini ingin melihat hubungan keduanya.

Kedua asumsi di ataslah yang menjadi dasar dalam pemilihan variabel dalam melakukan penelitian ini. Penelitian ini ingin memeriksa hubungan rasionalitas, fokusnya rasionalitas epistemik dengan inteligensi dan perfeksionisme. Dari hubungan tersebut maka akan diketahui apakah rasionalitas epistemik memiliki jaringan nomologis dengan inteligensi dan perfeksionisme. Selain itu, penelitian ini juga ingin memeriksa faktor laten yang terbentuk dari rasionalitas epistemik dengan inteligensi dan perfeksionisme.

Penelitian ini merupakan penelitian payung yang mana memiliki tujuan akhir menghasilkan sebuah alat ukur yang komprehensif untuk mengukur rasionalitas. Akan tetapi penelitian ini baru tahap awal yang fokus memeriksa konstrak rasionalitas sebagai konstrak yang masih belum diketahui independensinya dan faktor latennya.

Penelitian ini mengacu pada CART (Comprehensif Assessment Rational Test) yang dikembangkan oleh Stanovich. Stanovich, et al. (2016), membagi rasionaltas menjadi dua subtes, yaitu subtes rasionalitas instrumental dan subtes rasionalitas epistemik. Rasionalitas instrumental berkaitan dengan pengambilan keputusan yang didasari oleh keyakinan. Sedangkan rasionalitas epistemik berkaitan dengan keyakinan dengan melakukan penilaian serta pertimbangan.

Rasionalitas instrumental dan epistemik sebenarnya merupakan satu kesatuan. Akan tetapi di dalam penelitian ini fokusnya hanya pada rasionalitas epistemik. Alasan karena jumlah komponen pada subtes instrumental dan epistemik berjumlah sangat banyak sehingga tidak memungkinkan untuk dikaji semua dalam satu penelitian. Selain itu, konstrak rasionalitas epistemik masih belum diketahui eksistensi serta independensinya, oleh karena itu penelitian ini hanya mengkaji rasionalitas epistemik. Rasionalitas epistemik sendiri sangat dekat dengan istilah belief atau keyakinan. Loackard (2013) menyebutkan bahwa rasionallitas epistemik merupakan keyakinan seseorang yang dibentuk, dipelihara, dan juga diperbaiki sebagai jalan untuk mencapai sesuatu yang ingin dicapai. Rasionalitas epistemik merupakan hal yang sangat 
penting dan mendasar dalam sebuah pencapaian tujuan. Dengan keyakinan yang sesuai maka akan menjadikan manusia membuat keputusan yang baik sehingga tujuan dapat tercapai (Baron, 2008). Stanovich (2016) menambahkan bahwa rasionalitas epistemik merupakan dasar manusia dalam membuat keputusan yang rasional. Maka dari itu rasionalitas epistemik sangat perlu untuk diteliti.

Pemeriksaan konstrak rasionalitas dengan inteligensi dan perfeksionisme pada penelitian ini menggunakan jaringan nomologis yang dilihat dari konvergensi dan divergensi. Jaringan nomologis atau disebut juga validitas nomologis merupakan aspek dari validitas konstrak yang merepresentasikan bagaimana sebuah konstrak berkorelasi dengan konstrak lain (Roest \& Pieters, 1997). Sebuah konstrak dinyatakan eksis apabila membentuk jaringan nomologi dengan konstrak lain.

Walaupun masih tahap awal, tetapi penelitian ini menjadi dasar untuk pengembangan alat ukur rasionalitas selanjutnya. Alasan utama perlunya membuat alat ukur rasionalitas adalah pertama, selama ini inteligensi dianggap dapat mewakili rasionalitas, sehingga apabila mengukur inteligensi secara oto-matis mengukur rasionalitas (Stanovich, et al., 2016) alasan kedua belum ada alat ukur, terutama di Indonesia yang mengukur rasionalitas. Oleh karena itu sangat diperlukan alat ukur yang mengukur rasionalitas sesuai dengan budaya di Indonesia. Berdasarkan penjelasan di atas, peneliti ingin melihat apakah rasionalitas epistemik memiliki jaringan nomologis dengan inteligensi dan perfeksionisme dan faktor laten apa yang terbentuk dari rasionalitas epistemik, inteligensi, dan perfeksionisme?

\section{Metode}

\section{Subjek penelitian}

Pada penelitian ini, subjek yang dipilih adalah mahasiswa dari beberapa univer- sitas di Yogyakarta sebanyak 67 orang. Alasan utama memilih mahasiswa sebagai subjek dalam penelitian ini karena menurut Erikson, pada usia tersebut manusia tengah memasuki masa dewasa awal (Feist \& Feist, 2008). Pada tahap usia tersebut manusia akan banyak dihadapkan berbagai pilihan dalam hidupnya seperti pendidikan, pasangan, karir, dan lain-lain, sehingga diperlukan kemampuan berpikir rasional yang baik agar dapat membuat keputusan yang baik dalam hidup.

\section{Metode pengumpulan data}

Metode pengumpulan data pada penelitian ini menggunakan tes dan juga skala, yaitu Tes Rasionalitas Epistemik, Culture Fair Intelligence Test (CFIT), dan Frost Multidimentional Perfectionism Scale (FMPS). Tes Rasionalitas Epistemik yang digunakan di dalam penelitian ini menggunakan alat tes yang dikembangkan oleh Hidayat \& Widhiarso (2017) dari laporan penelitian yang belum dipublikasi. Tes tersebut mengacu pada Comprehensive Assessment of Rational Thinking (CART) yang dikembangkan oleh Stanovich, West \& Toplak (2016). Tes Rasionalitas Epistemik terdiri dari lima komponen yang mana setiap komponen memiliki sejumlah aitem. Culture Fair Intelligence Test (CFIT) merupakan alat tes yang dikembangkan oleh Raymon Cattel. CFIT merupakan salah satu alat tes untuk mengukur inteligensi yang mana berusaha menghindari unsur-unsur budaya di dalamnya. CFIT terdiri dari tiga skala, yaitu: Skala 1, Skala 2, dan Skala 3. Di dalam penelitian ini, menggunakan Skala 3 yang digunakan untuk orang dewasa. CFIT skala 3 terdiri dari empat subtes (Soekadji, 1980). Frost Multidimentioal Perfectionism Scale (FMPS) merupakan skala kepribadian yang mengukur perfeksionisme. FMPS ini dikembangkan oleh Frost, dkk pada tahun 1990 dan telah di adaptasi ke dalam bahasa 
Indonesia oleh Aditomo dan Retnowati pada tahun 2004 (Qur'ani, 2016).

\section{Hasil}

Berdasarkan analisis deskriptif pada tabel 1 maka diketahui bahwa rasionalitas epistemik, inteligensi, dan perfeksionisme memiliki rerata empirik yang lebih besar dibandingkan rerata hipotetik. Rerata empirik rasionalitas yaitu sebesar 296,8 lebih besar dari rerata hipotetik yaitu 250 . Inteligensi memiliki rerata empirik sebesar 51 lebih besar dari rerata hipotetik yaitu sebesar 50. Perbedaan tersebut sebenarnya tidak begitu jauh. Rerata empirik perfeksionisme adalah sebesar 88,7 lebih besar dari rerata hipotetik yaitu sebesar 87 . Dari hasil tersebut diketahui bahwa rasionalitas epistemik, inteligensi, dan perfeksionisme subjek penelitian lebih besar dari yang diperkirakan.

Berdasarkan tabel 2 maka dapat diketahui bahwa rasionalitas epistemik dan inteligensi memiliki nilai signifikasi sebesar 0,405 dan nilai $r-0,103$. Maka dapat dikatakan bahwa rasionalitas epistemik dan inteligensi tidak berkorelasi. Demikian pula rasionalitas epistemik dengan perfeksionisme memiliki nilai signifikansi sebesar 0,693 dan nilai r -0,049. Maka dapat dikatakan bahwa rasionalitas epistemik dengan perfeksionisme tidak memiliki korelasi. Dengan demikian dapat dikatakan bahwa rasionalitas epistemik pada level pengukuran tidak ada jaringan nomologis yang terbentuk pada rasionalitas epistemik dengan inteligensi, maupun rasionalitas epistemik dengan perfeksionisme.

Selain dilakukan korelasi antar variabel, penelitian ini juga melihat korelasi setiap komponen rasionalitas epistemik dengan variabel eksternal (tabel 3). Korelasi ini untuk melihat jaringan nomologis yang terbentuk pada setiap subtes rasionalitas epistemik dengan varia-bel eksternal, yaitu inteligensi dan perfeksionisme. Social norms dan inteligensi memiliki nilai signifikansi sebesar 0,472 dengan nilai $r \quad 0,089$, social norms dan perfeksionisme memiliki nilai signifikansi sebesar 0,135 dengan nilai $r \quad-0,143$. Avoidance of anchoring dan inteligensi memiliki nilai signifikansi sebesar 0,250 dengan nilai $\mathrm{r}-0,143$, avoidance of anchoring dan perfeksionisme memiliki nilai signifikansi sebesar 0,486 dengan nilai $r$ 1,087 . Under/overconfidence dan inteligensi memiliki nilai signifikansi sebesar 0,584 dengan nilai $\mathrm{r}$ sebesar $-0,680$, under/overconfidence dan perfeksionisme memiliki

Tabel 1.

Statistik Deskriptif

\begin{tabular}{|c|c|c|c|c|c|c|c|c|c|c|}
\hline \multirow[b]{2}{*}{ Variabel } & \multicolumn{5}{|c|}{ Hipotetik } & \multicolumn{5}{|c|}{ Empirik } \\
\hline & Range & Min & $\operatorname{Max}$ & $\tilde{x}$ & $S D$ & Range & Min & $\operatorname{Max}$ & $\tilde{x}$ & $S D$ \\
\hline $\begin{array}{l}\text { Rasionalitas } \\
\text { Epistemik }\end{array}$ & 500 & 0 & 500 & 250 & 83,3 & 113 & 238 & 351 & 296,8 & 27,7 \\
\hline Inteligensi & 100 & 0 & 100 & 50 & 16,7 & 31 & 34 & 65 & 51 & 7,1 \\
\hline Perfeksionisme & 116 & 29 & 145 & 87 & 19.3 & 88 & 40 & 128 & 88.7 & 17.2 \\
\hline
\end{tabular}

Tabel 2.

Uji korelasi rasionalitas epistemik dengan inteligensi, dan perfeksionisme

\begin{tabular}{lcc}
\multicolumn{1}{c}{ Hubungan } & $\mathbf{r}$ & $\mathbf{p}$ \\
\hline Rasionalitas Epistemik dan Inteligensi & $-0,103$ & 0,693 \\
Rasionalitas Epistemik dan Perfeksionisme & $-0,049$ & 0,405 \\
\hline
\end{tabular}


Tabel 3.

Uji korelasi komponen rasionalitas epistemik dengan inteligensi dan perfeksionisme

\begin{tabular}{lcc}
\hline \multicolumn{1}{c}{ Hubungan } & $\mathbf{r}$ & $\mathrm{p}$ \\
\hline Social Norms dan Inteligensi & 0,089 & 0,472 \\
Social Norms dan Perfeksionisme & $-0,143$ & 0,135 \\
Avoidance of Anchoring dan Inteligensi & $-0,143$ & 0,250 \\
Avoidance of Anchoring dan Perfeksionisme & 1,087 & 0,486 \\
Under/overconfidence dan Inteligensi & $-0,680$ & 0,584 \\
Under/overconfidence dan Perfeksionisme & $-0,132$ & 0,288 \\
Risk Perception dan Inteligensi & 0,080 & 0,519 \\
Risk Perception dan Perfeksionisme & $-0,001$ & 0,992 \\
Superstitious dan Inteligensi & $-0,099$ & 0,425 \\
Superstitious dan Perfeksionisme & 0,104 & 0,404 \\
\hline
\end{tabular}

Tabel 4.

Analisis factor komponen rasionalitas epistemik dengan inteligensi dan perfeksionisme

\begin{tabular}{lcc} 
& Komponen & 2 \\
\hline Recognizing Social Norms & 1 & \\
Avoidance of Anchoring & $-0,560$ & \\
Under/Overconfidence & 0,599 & $-0,724$ \\
Resistence to Risk Perception & $-0,360$ & 0,749 \\
Superstitous Thinking & & \\
Perfeksionisme & 0,604 & \\
Inteligensi & 0,508 & 0,415 \\
\hline
\end{tabular}

nilai signifikansi sebesar 0,288 dengan nilai $\mathrm{r}$ sebesar -0,132. Risk perception dan inteligensi memiliki nilai signifikansi sebesar 0,519 dengan nilai $\mathrm{r}$ 0,080, risk perception dan perfeksionisme memiliki nilai signifikansi sebesar 0,992 dengan nilai $\mathrm{r}-0,001$. Superstitious dan inteligensi memiliki nilai signifikansi sebesar 0,425 dengan nilai $\mathrm{r}-0,099$, superstitious dan perfeksionisme memiliki nilai signifikansi sebesar 0,404 dengan nilai r 0,104. Dari angka tersebut menunjukan bahwa subtes social norms, anchoring, overconfidence, risk perception, dan superstitious, masingmasing komponen tidak memiliki korelasi dengan inteligensi maupun perfeksionisme yang ditunjukan dengan nilai signifikansi lebih dari $0,05(\mathrm{p}<0,05)$.

Dari hasil analisis faktor pada tabel 4 , dapat diketahui bahwa komponen rasionalitas epistemik, inteligensi, dan perfeksionisme membentuk dua faktor. Faktor pertama terdiri dari recognizing social norms dengan loading factor sebesar -0,560, avoidance of anchoring dengan loading faktor sebesar 0,599, under/overconfidence dengan loading factor sebesar -0,360, superstitious thinking dengan loading factor sebesar 0,604, dan perfeksionisme dengan loading factor sebesar 0,508. Faktor kedua terdiri dari under/overconfidence dengan loading factor sebesar -0,724, risk perception dengan loading factor sebesar 0,749, dan inteligensi dengan loading factor sebesar 0,415.

Dari tabel tersebut dapat diketahui juga bahwa kelima komponen rasionalitas epistemik serta inteligensi dan perfeksionisme saling berkorelasi sehingga kemudian terbentuk dua faktor. Faktor pertama terdiri dari komponen recognizing social norms, avoidance of anchoring, superstitious thinking, perfeksionisme, dan inteligensi. Dari factor loading masing-masing komponen dapat diartikan bahwa semakin tinggi kemampuan manusia untuk menghindari anchor, kemampuan berpikir 
yang tidak takhayul, dan perfeksionisme, maka manusia tersebut dapat dikatakan memiliki kemampuan untuk mengenali norma sosial serta inteligensi yang rendah. Sebaliknya, apabila manusia memiliki inteligensi dan kemampuan untuk mengenali norma sosial yang tinggi, maka akan cenderung memiliki kemampuan untuk mengindari anchor yang rendah, percaya terhadap takhayul, dan perfeksionisme rendah. Hal tersebut dapat terlihat dari nilai factor loading pada faktor satu, recognizing social norms dan inteligensi memiliki nilai yang negatif.

Pada faktor dua, terdiri dari under/overconfidence, resistance to risk perception, dan inteligensi. Dari factor loading masing-masing komponen dapat diartikan bahwa semakin tinggi kemampuan manusia untuk menilai risiko dimasa depan dan semakin tinggi inteligensi, maka manusia tersebut semakin rendah kepercayaan diri yang dimiliki. Sebaliknya, semakin tinggi kepercayaan diri manusia, maka cenderung semakin rendah kemampuan manusia untuk menilai resiko di masa depan dan inteligensi. Hal tersebut dapat terlihat dari nilai factor loading pada faktor dua, under/overconfidence memiliki nilai yang negatif.

Akan tetapi pada hasil analisis faktor terlihat bahwa terdapat cross loading pada komponen under/overconfidence dan inteligensi. Pada komponen under/overconfidence terjadi cross loading pada faktor satu dan faktor dua. Pada faktor satu nilai factor loading sebesar -0,360, sedangkan pada faktor dua nilai faktor loading sebesar -0,724. Karena nilai factor loading pada faktor dua lebih besar dibandingkan pada faktor satu maka komponen under/overconfidence masuk ke dalam faktor dua. Cross loading selanjutnya terjadi pada inteligensi, yang mana inteligensi terdapat pada faktor satu maupun faktor dua. Pada faktor satu nilai factor loading sebesar $-0,400$, sedangkan pada faktor dua nilai factor loading sebesar 0,415 . Besar factor loading inteligensi pada kedua faktor tidak jauh berbeda, oleh karena inteligensi masuk ke dalam faktor satu maupun faktor dua.

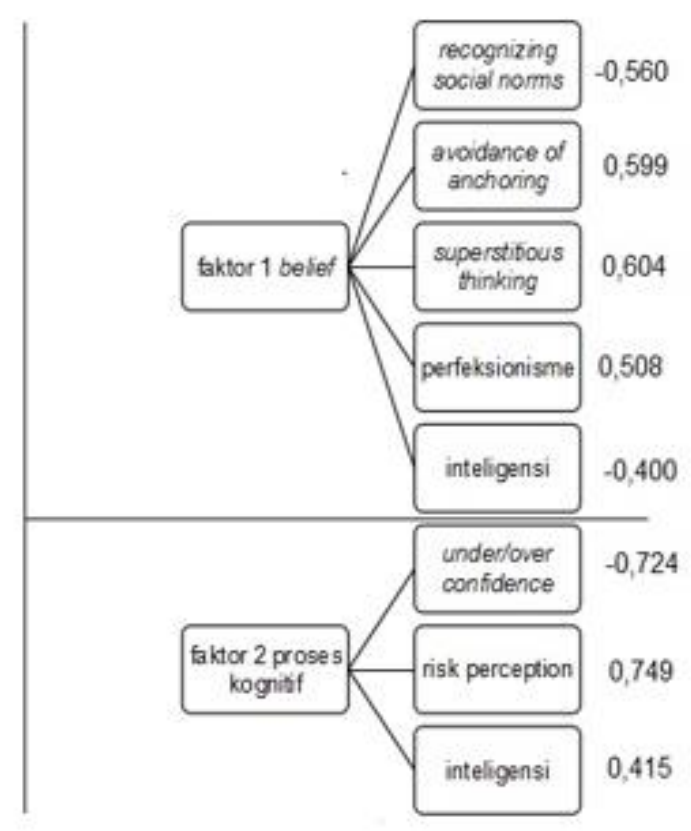

Gambar 1. Struktur konvergensi dan divergensi komponen rasionalitas epistemik, inteligensi dan perfeksionisme. 
Berdasarkan struktur pada Gambar 1 maka dapat diketahui bahwa terjadi konvergensi dan divergensi pada rasionalitas epistemik dengan inteligensi dan perfeksionisme. Konvergensi membentuk sebuah faktor yang mana komponen di dalamnya memiliki kedekatan atau kesamaan karakter, sehingga menjadi satu faktor. Faktor yang terbentuk dari konvergensi yaitu faktor satu yang terdiri dari komponen recognizing social norms, avoidance of anchoring, superstitious thinking, perfeksionisme, dan inteligensi. Berdasarkan kesamaan karakter dan dilihat aitem setiap komponen, maka peneliti memberikan nama faktor satu sebagai faktor belief. Selain faktor satu, konvergensi membentuk faktor dua yang terdiri dari under/overconfidence, risk perception, dan inteligensi. Berdasarkan kesamaan karakter dan dilihat aitem setiap komponen, maka peneliti memberikan nama faktor dua sebagai proses kognitif.

\section{Diskusi}

Berdasarkan hasil uji hipotesis antara variabel rasional epistemik, inteligensi, dan perfeksionisme, maka dapat dikatakan bahwa hipotesis alternatif pertama $\left(\mathrm{H}_{1}\right)$ diterima dan hipotesis null $\left(\mathrm{H}_{0}\right)$ ditolak. Hipotesis alternatif kedua $\left(\mathrm{H}_{2}\right)$ ditolak, dan hipotesis null $\left(\mathrm{H}_{0}\right)$ diterima. Hipotesis alternatif ketiga $\left(\mathrm{H}_{3}\right)$ diterima dan hipotesis null $\left(\mathrm{H}_{0}\right)$ ditolak.

Hipotesis alternatif pertama membuktikan bahwa rasionalitas epistemik dan inteligensi merupakan dua konstrak yang berbeda. Hal tersebut terbukti dari hasil uji interkorelasi yang pertama menyatakan bahwa rasionalitas epistemik dan inteligensi tidak berkorelasi. Bahkan penelusuran lebih lanjut dilakukan dengan menguji interkorelasi setiap komponen rasionalitas epistemik, yaitu recognizing social norms, avoidance of anchoring, under/overconfidence, consistency of risk perception, dan superstitious thinking dengan inteligensi menyatakan bahwa tidak ada komponen rasionalitas epistemik yang berkorelasi dengan inteligensi. Dengan hasil yang demikian maka penelitian ini mendukung penelitian yang dilakukan oleh Stanovich, Wes, dan Toplak (2016). Di dalam penelitian itu menyebutkan bahwa rasionalitas merupakan konstruk yang independen dari inteligensi. Oleh karena itu asumsi yang berkembang bahwa ketika mengukur inteligensi maka secara otomatis mengukur rasionalitas tidaklah berbukti. Nyatanya tidak ada komponen rasionalitas yang diukur oleh inteligensi. Penelitian ini juga semakin menguatkan adanya fenomena smart people acting dumb (Stanovich, West \& Toplak, 2012), yang artinya manusia yang memiliki inteligensi tinggi belum tentu mampu berpikir rasional. Manusia yang memiliki inteligensi tinggi belum tentu mampu membuat keputusan yang baik.

Akan tetapi pada hipotesis alternatif kedua tidak diterima, sehingga membuktikan bahwa rasionalitas epistemik dan perfeksionisme tidak memiliki korelasi. Artinya, manusia yang rasional secara epistemik belum tentu perfeksionis, walaupun keduanya memiliki kesamaan karakteristik yaitu keduanya menekankan pertimbangan yang matang dalam melakukan penilaian maupun dalam membuat sebuah keputusan. Tidak terbuktinya hubungan antara rasionalitas epistemik dan perfeksionisme dimungkinkan disebabkan oleh beberapa hal.

Tidak adanya hubungan antara rasionalitas dimungkinkan disebabkan karena berdasarkan plot ditemukan bahwa subjek pada penelitian ini bersifat homogen. Padahal subjek akan semakin baik apabila bersifat heterogen. Penyebabnya dimungkinkan karena jumlah subjek yang terlalu kecil sehingga tidak ada variasi subjek. Hal tersebut dapat terlihat dari data demografi, berdasarkan usia hampir setengahnya 
berusia 20-25 tahun. Dilihat dari jenis kelamin sebanyak $82,1 \%$ merupakan perempuan. Dilihat dari fakultas asal, sebanyak 67,2\% subjek berasal dari psikologi. Deskripsi subjek tersebut menjelaskan bahwa memiliki karakteristik yang kurang lebih sama dan variasi subjek penelitian sangatlah sedikit. Oleh karena itu, sangat dimungkinkan tidak adanya korelasi antara rasionalitas epistemik dengan perfeksionisme disebabkan karena subjek penelitian yang bersifat homogen.

Meskipun tidak ditemukan penelitian yang secara langsung menyatakan hubungan perfeksionisme dengan rasionalitas, namun terdapat hasil penelitian yang mendukung penelitian ini. Sebuah penelitian yang dilakukan oleh Flett, Hewitt, Blankstein \& Kaledin (1991) menyatakan bahwa ditemukan hubungan antara perfeksionisme dengan berpikir irasional. Berpikir irasional merupakan cara berpikir yang tidak logis serta tidak berdasarkan kenyataan (Macsinga \& Dobrita, 2010). Berpikir irasional berkebalikan dengan berpikir rasional yang sangat logis dan penuh pertimbangan. Oleh karena itu, tidak terbuktinya hubungan rasionalitas epistemik dengan perfeksionisme dalam penelitian ini dapat dipahami melalui hasil penelitian Flett, Hewitt, Blankstein \& Kaledin (1991). Dari uraian di atas menjelaskan, meskipun secara teori keduanya memiliki karakteristik yang sama, akan tetapi secara empiris keduanya memang tidak memiliki hubungan.

Berdasarkan hipotesis alternatif satu (H1) dan hipotesis alternatif kedua $(\mathrm{H} 2)$, maka dapat diketahui kaitannya dengan validitas nomologis bahwa rasionalitas epistemik tidak memiliki jaringan nomologis dengan inteligensi dan perfeksionisme pada level pengukuran. Akan tetapi di dalam penelitian ini tidak hanya memeriksa jaringan nomologis pada level pengukuran tetapi juga pada level konsep dan kedekatan antar ketiga variabel tersebut sebagai upaya untuk mempertahankan terbentuknya jaringan nomologis ketiga variabel. Oleh karena itu dilakukan analisis faktor untuk mengatahui hubungan ketiganya secara mendalam. Maka hipotesis alternatif tiga (H3) diterima, bahwa terjadi konvergensi dan divergensi pada rasionalitas epistemik dengan inteligensi dan perfeksionisme.

Konvergensi dan divergensi yang dimaksud yaitu kesamaan dan perbedaan karakteristik yang kemudian membuat komponen-komponen membentuk faktor. Melalui analisis faktor, hasil penelitian menunjukan bahwa terjadi konvergensi antara komponen rasionalitas epistemik dengan inteligensi dan perfeksionisme. Konvergensi terjadi akibat persamaan karakteristik yang kemudian membuat ketiga variabel tersebut membentuk dua faktor. Adapun faktor pertama yang terbentuk terdiri dari recognizing social norms, avoidance of anchoring, superstitious thinking, perfeksionisme, dan inteligensi, sedangkan faktor kedua terdiri dari under/overconfidence, consistency of risk perception, dan inteligensi. Divergensi terjadi akibat adanya perbedaan karakteristik komponen yang ada sehingga membuat komponen tersebut memisah membentuk dua faktor seperti yang telah disebutkan di atas.

Hasil analisis faktor komponen rasionalitas epistemik, inteligensi, dan perfeksionisme membentuk dua faktor. Faktor pertama diberi label "keyakinan" dan faktor kedua diberi label "proses kognitif". Seperti yang telah di jelaskan di atas bahwa faktor satu yaitu keyakinan terdiri dari recognizing social norms, avoidance of anchoring, superstitious thinking, perfeksionisme, dan inteligensi, sedangkan faktor kedua terdiri dari under/overconfidence, consistency of risk perception, dan inteligensi. Pemberian label pada faktor keyakinan didasarkan pada kesamaan fungsi pada setiap komponen di dalamnya. Gorman 
(1993) menyebutkan keyakinan merupakan sesuatu yang dapat mempengaruhi pikiran. Seperti halnya rasionalitas epistemik atau penilaian merupakan dasar dari rasionalitas. Sebelum mencapai rasionalitas instrumental atau pengambilan keputusan, terlebih dahulu seseorang melakukan penilaian mengenai kebenaran yang sesungguhnya. Manusia akan melakukan penilaian terhadap semua informasi atau alternatif yang diketahui. Penilaian tersebut kemudian mempengaruhi bagaimana manusia mengambil keputusan.

Untuk faktor kedua yaitu proses kognitif terdiri dari under/overconfidence, consistency of risk perception dan inteligensi. Pelabelan faktor proses kognitif juga didasari oleh fungsi dari setiap komponen. Di dalam faktor proses kognitif ini, komponennya mengukur kemampuan manusia untuk penyesuaian pengetahuan yang dimiliki dengan kenyataan yang sesungguhnya. Proses penyesuaian ini diperlukan proses kognitif di dalamnya, yang mana kita ketahui bahwa kogntif tidak terpisahkan dari inteligensi.

Yang menarik dari hasil penelitian ini, bahwa di dalam faktor keyakinan dan faktor proses kognitif terdapat inteligensi. Terjadi cross loading pada inteligensi dengan nilai faktor loading yang tidak berbeda jauh. Oleh karena itu inteligensi masuk ke dalam faktor keyakinan dan juga faktor proses kognitif. Hasil temuan ini menguatkan pendapat Stanovich dan West (2014) yang menyebutkan bahwa walaupun keduanya merupakan konstruk yang berbeda bahkan tidak memiliki korelasi, akan tetapi tidak lantas keduanya terpisah. Manusia memerlukan inteligensi untuk dapat berpikir secara rasional. Rasionalitas dan inteligensi memiliki hubungan yang saling tumpang tindih atau overlap. Temuan ini juga semakin menguatkan tripartite of mind (Stanovich, West, Toplak, 2012). Di dalam teori tersebut menyebutkan bahwa struktur berpikir manusia terdiri dari tiga tingkat, yaitu autonomus mind, algorithmic mind, dan reflective mind. Manusia yang mampu berpikir rasional, telah mencapai tingkatan ketiga yaitu reflective mind. Sedangkan algorithmic mind merupakan fluid intelligence manusia. Oleh karena itu manusia memerlukan inteligensi untuk mampu mencapai reflective mind supaya dapat berpikir secara rasional. Maka tidak mengherankan inteligensi berada di dalam kedua faktor laten yang terbentuk dari analisis faktor rasionalitas epistemik. Sebuah buku menjelaskan bahwa keyakinan dan kognisi mempengaruhi manusia dalam memutuskan tujuan dalam hidupnya (David, Lynn \& Ellis, 2010), yang mana telah dijelaskan sebelumnya bahwa rasionalitas pada hakikatnya merupakan cara berpikir terbaik untuk mendapat atau mencapai tujuannya. Dan kita ketahui bahwa kognisi merupakan bagian yang tidak terpisahkan dari inteligensi. Maka dalam setiap proses berpikir rasional, selalu akan dipengaruhi oleh keyakinan dan inteligensi.

Pengaruh inteligensi pada rasionalitas juga semakin diperkuat oleh eksperimen yang dilakukan oleh Fredrick (2005) yang dikenal dengan bat and ball problem. Penelitian tersebut menunjukan bahwa Cognitive Reflection Test (CRT) berpengaruh pada time preference dan risk preference yang mana keduanya merupakan salah satu komponen rasionalitas. Penelitian ini menunjukan bahwa walaupun terdapat pengaruh kemampuan kognitif maupun inteligensi dalam proses berpikir rasional. Akan tetapi perlu ditegaskan lagi bahwa keduanya merupakan konstrak yang terpisah.

Berdasarkan konvergensi dan divergensi yang terjadi, maka dapat diakatakan bahwa rasionalitas epistemik, inteligensi, dan perfeksionisme membentuk jaringan nomologis. Meskipun pada level pengukuran ketiganya tidak 
membentuk jaringan nomologis, namun pada level konsep ketiganya membentuk jaringan nomologis. Terbukti dengan adanya struktur konvergensi dan divergensi yang terbentuk. Faktor keyakinan dan faktor proses kognitif, di dalamnya terdiri dari komponen-komponen yang saling berdekatan dan berhubungan sehingga membentuk faktor. Kedekatan antar komponen itulah yang di dalam penelitian ini disebut dengan jaringan nomologis.

Dari hasil penelitian ini dapat diketahui pula bahwa pada level pengukuran, rasionalitas epistemik dan inteligensi merupakan dua konstruk yang berbeda. Menurut Azwar (2012) validitas yang baik ditunjukan oleh dua pengukuran terhadap trait yang sama memiliki korelasi yang tinggi. Sebaliknya, apabila kedua pengukuran menunjukan korelasi yang rendah maka keduanya memang mengukur atribut yang berbeda. Dari hasil korelasi rasionalitas epistemik dan inteligensi menunjukan bahwa keduanya memiliki koefisien dan nilai signifikasi yang rendah. Maka dapat dikatakan bahwa keduanya merupakan konstruk yang berbeda dan tidak dapat diwakilkan pengukurannya. Temuan ini agaknya memberikan wacana baru diberbagai bidang mengenai perlunya untuk mulai mempertimbangkan rasionalitas sebagai salah satu faktor yang diukur dalam rekruitmen atau asesmen, mengingat bahwa inteligensi masih dianggap menjadi prediktor yang baik kinerja seseorang (Nisbett, Aronson, Blair, Dickens, Flynn, Halpern \& Turkheimer, 2012). Akan tetapi perlu juga diketahui bahwa muara dari berbagai kemampuan yang dimiliki manusia dan penilaian yang dilakukan berakhir pada pembuatan keputusan. Terutama di dalam setting organisasi, pembuatan keputusan merupakan sesuatu yang sangat krusial (Al-Tarawneh, 2012). Bahkan pertumbuhan sebuah organisasi merupakan hasil dari pembuatan keputusan (Daft, 2013). Oleh karenanya, keputusan yang baik atau keputusan yang rasional sangat diperlukan dan diperhatikan prosesnya. Sebelum membuat keputusan, biasanya manusia dihadapkan oleh berbagai alternatif dan informasi. Untuk dapat mencapai keputusan yang baik, diperlukan berpikir rasional agar keputusan yang dibuat sesuai dan tepat dengan apa yang menjadi tujuan, sedangkan kemampuan berpikir rasional tidak diukur di dalam tes inteligensi (Stanovich, 2016). Oleh karena itu, mempertimbangkan rasionalitas sebagai salah satu alat ukur di dalam asesmen maupun rekruitmen sangatlah penting.

Berdasarkan uraian mengenai hasil penelitian di atas, maka dapat disimpulkan bahwa rasionalitas epistemik tidak memiliki hubungan dengan inteligensi dan perfeksionisme. Artinya, rasionalitas epistemik tidak memiliki jaringan nomologis dengan inteligensi dan perfeksionisme pada level pengukuran. Akan tetapi pada level konsep ketiganya membentuk jaringan nomologis berdasarkan struktur konvergensi dan divergensi yang dilihat dari hasil analisis faktor. Hasil analisis faktor menunjukan bahwa terjadi konvergensi dan divergensi antara rasionalitas epistemik, inteligensi, dan perfeksionisme, yang membentuk dua faktor. Faktor pertama adalah keyakinan, sedangkan faktor kedua adalah proses kognitif. Artinya, rasionalitas epistemik di dalamnya terdapat fungsi keyakinan dan proses kognitif.

\section{Kesimpulan}

Rasionalitas epistemik yang diukur dengan menggunakan subtes rasionalitas epistemik tidak memiliki hubungan dengan inteligensi yang diukur dengan menggunakan CFIT. Rasionalitas epistemik dan inteligensi tidak memiliki 
hubungan nomologis karena tidak terbentuk jaringan nomologis diantara keduanya. Hal tersebut menunjukan bahwa rasionalitas epistemik merupakan konstrak yang independen dari inteligensi. Tidak ada komponen dari rasionalitas epistemik yang diukur di dalam inteligensi. Maka hasil ini mendukung asumsi yang diungkapkan oleh Stanocivh, West \& Toplak, 2016) yang menyebutkan bahwa rasionalitas epistemik dan inteligensi merupakan dua konstrak yang independen karena kedua tidak saling mewakili satu sama lain.

Selain tidak memiliki hubungan dengan inteligensi, rasionalitas juga tidak memiliki hubungan dengan perfeksionisme yang diukur dengan FMPS. Hasil tersebut menjelaskan bahwa manusia yang rasional secara epistemik tidak selalu perfeksionisme, begitupun sebaliknya meskipun keduanya memiliki karakteristik yang sama yaitu sama-sama melakukan pertimbangan yang matang dalam rangka mendapatkan pilihan yang terbaik. Maka hasil ini menjelaskan bahwa pada level pengukuran rasionalitas epistemik tidak memiliki jaringan nomologis dengan perfeksionisme.

Akan tetapi meskipun pada level pengukuran rasionalitas tidak memiliki jaringan nomologis dengan inteligensi dan perfeksionisme, pada level konsep ketiganya membentuk jaringan nomologis. Jaringan nomologis yang terbentuk antara rasionalitas epistemik dengan inteligensi dan perfeksionisme terlihat dari struktur konvergensi dan divergensi dari analisis faktor. Konvergensi dan divergensi dari analisis faktor penelitian ini menghasilkan dua faktor laten, yaitu faktor keyakinan dan faktor proses kognitif.

Faktor keyakinan, terdiri dari lima komponen. Komponen-komponen tersebut yaitu recognizing social norms, avoidance of anchoring, belief in superstitious thinking, perfeksionisme, dan inteligensi. Di dalam faktor keyakinan ini kelima komponen ini memiliki kesamaan karakter sehingga kelimanya saling berdekatan membentuk satu faktor. Faktor keyakinan ini di dalamnya berkitan dengan sesuatu yang diyakini atau dipercaya manusia untuk disesuaikan dengan kenyataan yang sesungguhnya. Penyesuaian tersebut membutuhkan proses berpikir, sehingga tidak mengherankan di dalam faktor keyakinan terdapat inteligensi di dalamnya.

Faktor proses kognitif, terdiri dari tiga komponen. Komponen-komponen tersebut yaitu under/overconfidence, consistency of risk perception dan inteligensi. Ketiganya memiliki kemiripan sehingga saling berdekatan membentuk faktor proses kognitif. Faktor proses kognitif ini di dalamnya berkaitan dengan proses berfikir manusia dalam rangka mengkonfirmasi mengetahui atau informasi yang diyakini.

Kedua faktor itulah yang terbentuk dari hasil analisis faktor yang kemudian dilihat struktur konvergensi dan divergensinya. Dari struktur konvergnsi dan divergensi yang tebentuk, maka dapat dikatakan bahwa rasionalitas epistemik memiliki jaringan nomologis dengan inteligensi dan perfeksionisme.

Saran

Hasil pada penelitian ini memberikan sedikit gambaran mengenai rasionalitas dan sekaligus memberikan peluang yang lebih besar kepada peneliti selanjutnya untuk lebih memperdalam mengenai rasionalitas, terutama rasionalitas epistemik. Akan tetapi terdapat beberapa hal yang perlu diperhatikan untuk peneliti selanjutnya. Pertama, penggunaan CBT (computer based test) pada penelitian ini perlu dipertimbangkan dan dievaluasi mengingat subjek penelitian diharuskan untuk datang ke lokasi yang sudah menyediakan CBT, sehingga sedikit menyulitkan. Kedua, waktu pengerjaan yang cukup lama dikarenakan jumlah soal yang sangat 
banyak, sehingga perlu evaluasi instrumen atau menyediakan tempat yang nyaman bagi subjek agar pengambilan data berjalan lancar.

Selain saran bagi peneliti selanjutnya, penelitian ini juga memberikan wacana baru bahwa asumsi yang menyamakan rasionalitas dan inteligensi tidakah benar. Tes inteligensi selama ini dianggap mampu mengukur rasionalitas manusia, padahal nyatanya tidak ada satupun komponen rasionalitas yang diukur dalam tes inteligensi. Oleh karena itu penelitian ini menawarkan sebuah alternatif untuk mempertimbangkan rasionalitas sebagai kemampuan yang perlu diukur untuk asesmen maupun rekruitmen, terutama pada level manager sebagai pembuat keputusan di level organisasi.

\section{Daftar Pustaka}

Aditomo, A. \& Retnowati, S. (2004). Perfeksionisme, harga diri, dan kecenderungan depresi pada remaja akhir. Jurnal Psikologi, 31(1), 1-14. doi: 10.22146/jpsi.7033

Al-Tarawneh, H. A. (2012). The main faktors beyond decision making. Journal of Management, 4(1), 1-23. doi: https://doi.org/10.5296/jmr.v4i1.1184

Azwar, S. (1996). Pengantar psikologi inteligensi. Yogyakarta: Pustaka Pelajar.

Azwar, S. (2012). Penyusunan skala psikologi. Yogyakarta: Pustaka Pelajar.

Baron, J. (2008). Thinking and deciding. New York: Cambridge University Press.

Daft, Richard L. (2013). Management 11th edition. US: Cengage Learning;

Ellis, A., David, D., \& Lynn, S. J. (2010). Rational and irrational beliefs: A historical and conceptual perspective. In D. David, S. J. Lynn, \& A. Ellis (eds.), Rational and irrational beliefs: Research, theory, and clinical practice (pp. 3-22). New York: Oxford University Press.

Feist, J. \& Feist, G. J. (2008). Theories of personality. Yogyakarta: Pustaka Pelajar.

Flett, G. L., Hewitt, P. L., Blankstein, K. R. \& Kaledin, S. (1991). Dimensions of perfectionism and irrational thinking. Journal of Rational-Emotive \& CognitiveBehavior Therapy, 9(3), 185-201.

Frederick, S. (2005). Cognitive reflection and decision making. Journal of Economic Perspectives, 19, 25-42. doi: $\underline{10.1257 / 089533005775196732}$

Gigerenzer, G. (2001). Bounded rationality: The adaptive toolbox. The MIT Press: Cambridge, Massachusetts, London.

Gorman, M. M. (1993). Hume's theory of belief. Hume Studies, 19(1), 89-102.

Hastie, R., \& Dawes, R. M. (2010). Rational choice in an uncertain world: The psychology of judgment and decision making (2nd ed.). Thousand Oaks, CA, US: Sage Publications, Inc.

Hidayat, R. (2016). Rasionalitas overview terhadap pemikiran dalam 50 tahun terakhir. Buletin Psikologi, 24(2), 101122. doi: 10.22146/buletinpsikologi. 26772

Hidayat, R., \& Widhiarso, W. (2017). Pengembangan tes rasionalitas individu. Naskah Tidak Terpublikasi: Laporan Hibah Multiyear Fakultas Psikologi Universitas Gadjah Mada.

Lea, S.,E.,G. (1994) Rationality: The formalist view. In: Brandstätter $\mathrm{H}$., Güth W. (eds) Essays on Economic Psychology. Springer, Berlin, Heidelberg. doi: 10.1007/978-3-64248621-0 4

Loackhard, M. (2013). Epistemic instrumentalism. Synthese, 190(9), 1701-1718.

Macsinga, I. \& Dobrita, O. (2010). More educated, less irrational: Gender and 
educational differences in perfectionism and irrationality. Romanian Journal of Applied Psychology, 12(2), 7985.

McFadden, D. (1998). Rationality for econimist?. Journal of Risking and Uncertaint, 19(1-3), 73-105. doi: 10.1023/A:1007863007855

Munier, B., Selten, R., Bouyssou, D., Bourgine, P., Day, R. Harvey, N., Hilton, D., Machina M. J., Parker, Ph., Sterman, J., Weber, E., Wernerfelt, Wensley, R. (1999). Bounded rationality modeling. Marketing Letters, 10(3), 233-248. doi: 10.1023/A:10080 58417088

Nisbet, R. E., Aronson, J., Blai, C., Dickens, W., Flyyn, J., Halpern, D. F. \& Turkheimer. (2012). Intelligence: New findings and theoritical developments. American Psychological Association, 67(2), 130-159. doi: $\underline{10.1037 / a 0026699}$

Qur'ani, A. N. (2016). Hubungan perfeksionisme dan leader member exchange dengan stress kerja di era globalisasi. (Skripsi, tidak diterbitkan). Fakultas Psikologi, Universitas Gadjah Mada.

Roest, H. \& Pieters, R. (1997). The nomological net perceived service quality. International Journal of Service Industry Management, 8(4), 336-351. doi: $\underline{10.1108 / 09564239710174408}$

Russell, S. (1997). Rationality and intelligence. Artificial Intelligence, 94, 57-77. doi: 10.1016/S00043702(97)00026-X

Schwartz, B., Ward, A., Monterosso, J., Lyubomirsky, S., White, K., \& Lehman, D. R. (2002). Maximizing Vs satisficing: Happiness is a matter of choice. Journal of Personality and Social Psychology, 83(5), 1178-1197.
Simon, H. A. (1955). A behavioral model od rational choice. The Quarterly Journal of Economics, 69(1), 99-118. doi: $\underline{10.2307 / 1884852}$

Simon, H. A. (1976) "From substantive to procedural rationality", in Spiro J. Latsis, Method and Appraisal in Economics, Cambridge: Cambridge University Press: 129-148.

Simon, H. (1972). Theories of bounded rationality. In: C. B. McGuire, \& R. Radner (Eds.), Decisionand Organization (pp. 161-176). Amsterdam: North-Holland.

Simon, H. A. (1978). Rationality as process and as product thought. The American Economic Review, 68(2), 1-16.

Sirois, F. M. \& Molnar, D. S. (2016). Perfectionism, health and well being. Switzerland: Springer International Publishing.

Soekadji, S. (1980). Memperkenalkan culture fair intelligegnce test, dll. Yogyakarta.

Stanovich, K. E. \& West, R. F. (2008). On the relative independence of thinking biases and cognitive ability. Journal Perspective Social Psychology, 94(4), 672695. doi: $10.1037 / 0022-3514.94 .4 .672$

Stanovich, K. E. \& West, R. F. (2014). The assement of rational thinking: IQ $\neq$ RQ. SAGE: Teaching of Psychology, 4(3), 265-271. doi: 10.1177/0098628314 $\underline{537988}$

Stanovich, K. E. (2016). The comprehnsive assessment of rational thinking. Routledge Taylor $\mathcal{E}$ Francis Group: Educational Psychology, 51(1), 23-34. doi: $\underline{10.1080 / 00461520.2015 .1125787}$

Stanovich, K. E., West, R. \& Toplak, M. (2016). The rationality question toward a test of rational thinking. Cambridge: Massachusetts Institute of Technology Press. 
Sternberg, R.t J. (1997). Successfull intelegence: How practical and creative intellegence determine success in life. United States of America: A Plume Book.
Walter, J., Kellermanns, F. W. \& Lechner, C. (2012). Decision making within and between organization: Rationality, politics, and alliance performance. Journal of Management, 38(5), 15821610. 